\title{
Stony corals in Dominica during the 2005 bleaching episode and one year later
}

\author{
S.C.C. Steiner \& J.M. Kerr \\ Institute for Tropical Marine Ecology Inc. (ITME) P.O. Box 944, Roseau, Commonwealth of Dominica; \\ admin@itme.org
}

Received 13-VII-2007. C Corrected 01-XI-2007. ～Accepted 13-II-2008.

\begin{abstract}
In 2005, the Atlantic and Gulf Rapid Reef Assessment protocol (AGRRA v. 4) was implemented for the first time in Dominica between October 20 and November 18. During that time elevated sea surface temperatures were initiating the most severe bleaching episode so far recorded for the northeastern and eastern Caribbean. Nineteen of the 20 species of stony corals within the survey were affected. The occurrence of pale, partially bleached or completely bleached colonies exceeded $50 \%$ in 13 of these species, and $76 \%$ of all colonies $(n=1475)$ had some symptom of bleaching. In an effort to assess the impact of this event on Dominica's stony corals, the sixteen sites studied in 2005 were revisited in 2006 (October 17 - November 25) and resurveyed using the same methods. Twenty of the 23 species within the survey were affected, yet the occurrence of pale, partially bleached or completely bleached colonies exceeded $50 \%$ in only four of these species. Twenty-six percent of all colonies $(n=1407)$ had some symptom of bleaching. However, live coral cover had decreased by $28 \%$, recent mortality had increased by $10 \%$, and the abundance of coral recruits had decreased by $65 \%$. Agaricia agaricites was among the most affected species having been a common coral on Dominica's reefs until 2005, yet absent in the 2006 survey. Deep sites (6-18m) were more affected by recent coral mortality than shallow sites, undermining the extent to which they may serve as refugia. The 2005 bleaching episode in Dominica followed those of 2003 and 2004. Given the increasingly chronic nature of such events, and the common disturbances of sediment runoff (quarries, coastal development), contamination (solid waste, sewage, pesticides), and fishing (spear fishing, traps, seine nets), Dominica's marginal reef systems are being exposed to an unprecedented load of stressors. This scenario highlights the urgency of immediate action in reducing local disturbances if the island's coral reef resources are to have a chance of being conserved. Rev. Biol. Trop. 56 (Suppl. 1): 139-148. Epub 2008 May 30.
\end{abstract}

Key words: coral bleaching, Dominica, mortality, recruitment.

Thermal stress in the form of prolonged periods of anomalously elevated temperatures is among the principal causes inducing regional mass bleaching in stony corals and other zooxanthellate Cnidaria (Jokiel and Coles 1990, Lesser et al. 1990, Williams and BunkleyWilliams 1990, Glynn 1993, Hoegh-Guldberg 1999). In 2005 coral bleaching throughout the Caribbean was linked to the warmest thermal stress event recorded for the region (Shein 2006). Coral bleaching and sea surface temperature data gathered throughout the Caribbean place the epicenter of this event in the eastern Caribbean (C. M. Eakin et al. in prep.).
Dominica's coral reefs and habitats are shaped by its narrow island shelf. With the exception of the region between Mero and Batali, west coast "reefs" are primarily composed of coral assemblages established on volcanic rock with limited reef accretion due to marginal protection from natural terrestrial and oceanic disturbances (Steiner 2003). Madracis mirabilis banks and assemblages (intermittently harboring colonies of Porites porites) also form an essential component of the west coast reefs. An extensive fringing reef system, with Acropora palmata as important constructional component, is found along the north east 
coast between Anse Du Mé and Marigot. The rest of the east coast is characterized by a few sheltered bays harboring fringing reefs in 1$10 \mathrm{~m}$ (Steiner 2003), while deep reefs remain unexplored.

The close spatial proximity between reefs and Dominica's population centers, given the steep island terrain, has exposed these resources to a multitude of local chronic stressors (e.g. coral mining, fishing, sedimentation) for at least 3 centuries. With the increase of regional and global disturbances such as bleaching events (Hoegh-Guldberg 1999), reefs of Dominica continue to change rapidly. By quantifying the destructive nature of global threats such as rising sea surface temperatures (a phenomenon not easily mitigated by small island nations), the urgency of managing local chronic disturbances which can be mitigated locally is highlighted.

This study assesses the effect of the 2005 bleaching episode on Dominica's coral community, based on standardized surveys (AGRRA v.4) implemented in 2005, during the bleaching episode and repeated one year later. Species composition, live coral cover, recent coral mortality and the abundance of coral recruits determined during the 2005 and 2006 surveys were compared.

\section{MATERIALS AND METHODS}

Between October 20 and November 18 of 2005, 16 reefs and coral assemblages (Table 1) were strategically selected and surveyed following the Atlantic and Gulf Rapid Reef Assessment v. 4.0 benthos protocols (Kramer et al. (2005). With the exception of Calibishie, all sites are located on the leeward side of the island. Although not considered "true reefs", rocky substrates harboring scleractinian coral communities were included because they represent common reefal habitats in Dominica (Steiner 2003). Large mono-specific banks of

TABLE 1

Survey sites, coordinates, depth, survey date, and number of transects $(T)$ surveyed

\begin{tabular}{|c|c|c|c|c|c|c|c|}
\hline Site Name & Acronym & Latitude N & Longitude W & Depth m & $\begin{array}{c}\text { Survey } \\
2005\end{array}$ & $\mathrm{~T}$ & $\begin{array}{c}\text { Survey } \\
2006\end{array}$ \\
\hline Calibishie & $\mathrm{Ca}$ & 15.354113 & 61.204523 & $1-5$ & 25.10 & 18 & 15.11 \\
\hline Colihaut & Co & 15.285124 & 61.264058 & $2-5$ & 18.11 & 6 & 9.11 \\
\hline Batali Beach & $\mathrm{BB}$ & 15.265708 & 61.265516 & $2-5$ & 17.10 & 4 & 1.11 \\
\hline Floral Gardens & FG & 15.265257 & 61.270216 & $15-18$ & 27.10 & 8 & 13.11 \\
\hline Rena's Reef & RRf & 15.262896 & 61.271164 & $10-15$ & 1.11 & 9 & 11.11 \\
\hline Brain Reef & $\mathrm{BR}$ & 15.115004 & 61.244305 & $12-15$ & 2.11 & 7 & 6.11 \\
\hline Salisbury E & SE & 15.261957 & 61.264058 & $1-5$ & 20.10 & 6 & 20.10 \\
\hline Salisbury W & SW & 15.261801 & 61.264413 & $12-15$ & 25.10 & 9 & 27.10 \\
\hline Macoucheri & $\mathrm{M}$ & 15.254762 & 61.261284 & $1-5$ & 3.11 & 6 & 25.11 \\
\hline Barry’s Dream & $\mathrm{BD}$ & 15.250606 & 61.255968 & $10-15$ & 7.11 & 8 & 31.11 \\
\hline Rodney’s Rock & RRk & 15.225004 & 61.244305 & $1-5$ & 2.11 & 11 & 3.11 \\
\hline Fond Cole & FC & 15.190880 & 61.233742 & $1-5$ & 29.10 & 9 & 2.11 \\
\hline Champagne E & $\mathrm{CE}$ & 15.143888 & 61.222315 & $1-5$ & 12.11 & 6 & 26.10 \\
\hline Champagne W & CW & 15.143806 & 61.222562 & $6-10$ & 12.11 & 6 & 16.11 \\
\hline Scotts Head N & $\mathrm{SN}$ & 15.125163 & 61.221292 & $12-15$ & 13.11 & 6 & 16.11 \\
\hline Scotts Head S & SS & 15.124947 & 61.221476 & $1-5$ & 13.11 & 6 & 8.11 \\
\hline
\end{tabular}


Madracis mirabilis were not included in the quantitative surveys. The survey coincided with a severe coral bleaching episode, linked to prolonged elevated sea surface temperatures, which in Dominica rose between mid March to mid August from $28^{\circ} \mathrm{C}$ to $30^{\circ}+\mathrm{C}$, where they remained until the end of October before decreasing. Temperature measurements were collected in the field with a lab grade thermometer and compared to SST satellite data provided by NOAA (http://coralreefwatch.noaa.gov). The approximate onset of this episode was determined from qualitative field observations from August 2005. In order to assess the effect of this event, the same sites were re-surveyed in 2006 between October 17 and November 25 with the same survey method (Tab. 1). In 2006 sea surface temperatures were at $26.5^{\circ} \mathrm{C}$ in March, reaching $30^{\circ}$ in late August, where they remained until mid October before decreasing.

Sites deeper than $5 \mathrm{~m}$ were surveyed using SCUBA equipment. Prior to data collection divers engaged in consistency training by examining the same transects and comparing measurements. Two transects on land (mock reef) and 3 transects on reefs were necessary to achieve homogenous results with the group. In situ coral identification was based on Humann (1994). One-hundred-twenty five and 132 haphazardly located, 10-m benthic contact transects were examined in 2005 and 2006, respectively. Comparisons of live cover, bleaching prevalence and recent mortality are based on data for corals $\geq 10 \mathrm{~cm}$ in diameter (see Kramer et al. 2005). The abundance of coral recruits was assessed based on 625 and 660 (0.0625 $\mathrm{m}^{2}$ quadrats) in 2005 and 2006, respectively. Two statistical tests were performed to determine the presence of significant differences. A one-tailed two population proportion (TPP) test (Ramsey 1997) was used to test hypotheses regarding prevalence of bleaching, linear coral cover, and surface area estimates and a one-tailed two-sample t-test (Ramsey 1997) was used to test hypotheses on recruit density.

\section{RESULTS}

The first signs of coral bleaching in 2005 became evident in late August, initially affecting Porites porites throughout the island, while massive framework building species such as Montastraea faveolata and Montastraea annularis started showing symptoms approximately three weeks later. By the time this study was executed, 19 of the 20 species within the 2005 survey, and $76 \%$ of all colonies $(n=1475)$ had some symptom of bleaching (Table 2). In 13 species the number of colonies which were affected by bleaching exceeded 50\%. Within this group, $60-83 \%$ of all colonies among the massive framework building species $M$. annularis, M. faveolata, Montastraea cavernosa, Diploria strigosa and Siderastrea siderea were affected. Among the common smaller species, $P$. astreoides, $P$. porites and Meandrina meandrites, the percentage of colonies affected ranged between 56 and $83 \%$. Agaricia agaricites showed signs of bleaching in 101 of the 109 colonies surveyed. Seventeen percent of all surveyed colonies were fully bleached (Fig. 1).

In 2005, all shallow sites (1-5m) had a significantly higher prevalence of bleaching symptoms as well as significantly more fully bleached corals than deep sites (6-18m) (TPP, z $=2.75, \mathrm{p}<0.01)$. However, no significant difference between shallow and deep sites was found in tissue loss due to recent mortality which affected $1 \%$ or $2.1 \mathrm{~m}^{2}$ of the total examined coral cover. Although 5 of the 14 surveyed colonies of $M$. mirabilis showed signs of bleaching, the large M. mirabilis banks of Mero and Grand Savane did not appear bleached. The first signs of corals regaining zooxanthellae were observed in mid November 2005.

In 2006, three additional species, Dendrogyra cylindrus ( $\mathrm{n}=2), \quad$ Meandrina brasiliensis $(\mathrm{n}=2)$, and Mussa angulosa $(\mathrm{n}=1)$ were within the surveyed transects, but not a single live colony of $A$. agaricites. Twenty-six percent of all colonies $(n=1407)$ exhibited some symptom of bleaching (Tab. 2, Fig. 1). The occurrence of pale, partially bleached or 
TABLE 2

Species abundance, live cover, colonies with bleaching symptoms and recent mortality in 2005 and 2006 surveys

2005

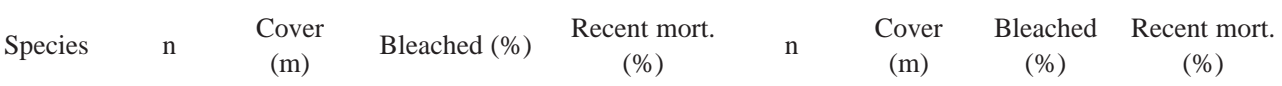

$1 \quad$ SINT $\quad 6 \quad 0.59$

$2 \quad$ MMIR $42 \quad 5.93$

3 MDEC $4 \quad 0.17$

$4 \quad$ APAL $\quad 7 \quad 2.91$

$5 \quad$ SSID $\quad 116 \quad 34.28$

$6 \quad$ AAGA $\quad 109 \quad 8.02$

$\begin{array}{llll}7 & \text { MMEA } & 162 & 18.04\end{array}$

8 MBRA 0 -

$\begin{array}{llll}9 & \text { DSTO } & 4 & 0.39\end{array}$

10 DCYL 0

11 MANG 0

12

ISIN

13

CNAT

4

0.47

5.40

DSTR

23

6.29

DCLI

42

6.29

1.12

0.53

DLAB 5

8.89

22.45

5.70

1.36

14.75

PPOR 94

59.80

PAST 556

15.92

MMIL 140

Total: $\quad 1,475$

210.1 (m)

(\%)

(\%)
2006

100
14
0
43
65
93
56
-
50

$15 \quad 1.16$

$32 \quad 5.01$

$13 \quad 0.41$

$6 \quad 3.09$

$152 \quad 38.91$

$$
0
$$

200

21.78

0.21

0.73

0.16

0.18

0.05

5.75

6.82

2.48

1.26

8.28

20.40

6.94

0.15

2.31

35.84

24.88

186.8
53

18

16

23

46

$$
17
$$

33

$$
2
$$$$
7
$$

-

$50 \quad 0$

$8 \quad 11$

$0 \quad 0$

$50 \quad 28$

$35 \quad 12$

514

$56 \quad 3$

$10 \quad 11$

$43 \quad 11$

$46 \quad 23$

$28 \quad 6$

$50 \quad 49$

$80 \quad 11$

$14 \quad 17$

$20 \quad 5$

$26 \quad 11$

$28 \quad 5$

$0 \quad 0$

Species abundance (n), live cover (m), colonies with bleaching symptoms (\%) and recent mortality (\% tissue loss) in 2005 and 2006 surveys. Species abbreviations 1-22 (Scleractinia, Anthozoa) and 23 (Milleporina, Hydrozoa): SINT Stephanocoenia intersepta, MMIR Madracis mirabilis, MDEC Madracis decactis, APAL Acropora palmata, SSID Siderastrea siderea, AAGA Agaricia agaricites forma agaricites, MMEA Meandrina meandrites, MBRA Meandrina brasiliensis, DSTO Dichocoenia stokesi, DCYL Dendrogyra cylindrus, MANG Mussa angulosa, ISIN Isophyllia sinuosa, CNAT Colpophyllia natans, DSTR Diploria strigosa, DCLI Diploria clivosa, DLAB Diploria labyrinthiformis, MANN Montastraea annularis, MFAV Montastraea faveolata, MCAV Montastraea cavernosa, EFAS Eusmilia fastigiata, PPOR Porites porites, PAST Porites atsreoides, MILL Millepora spp. 

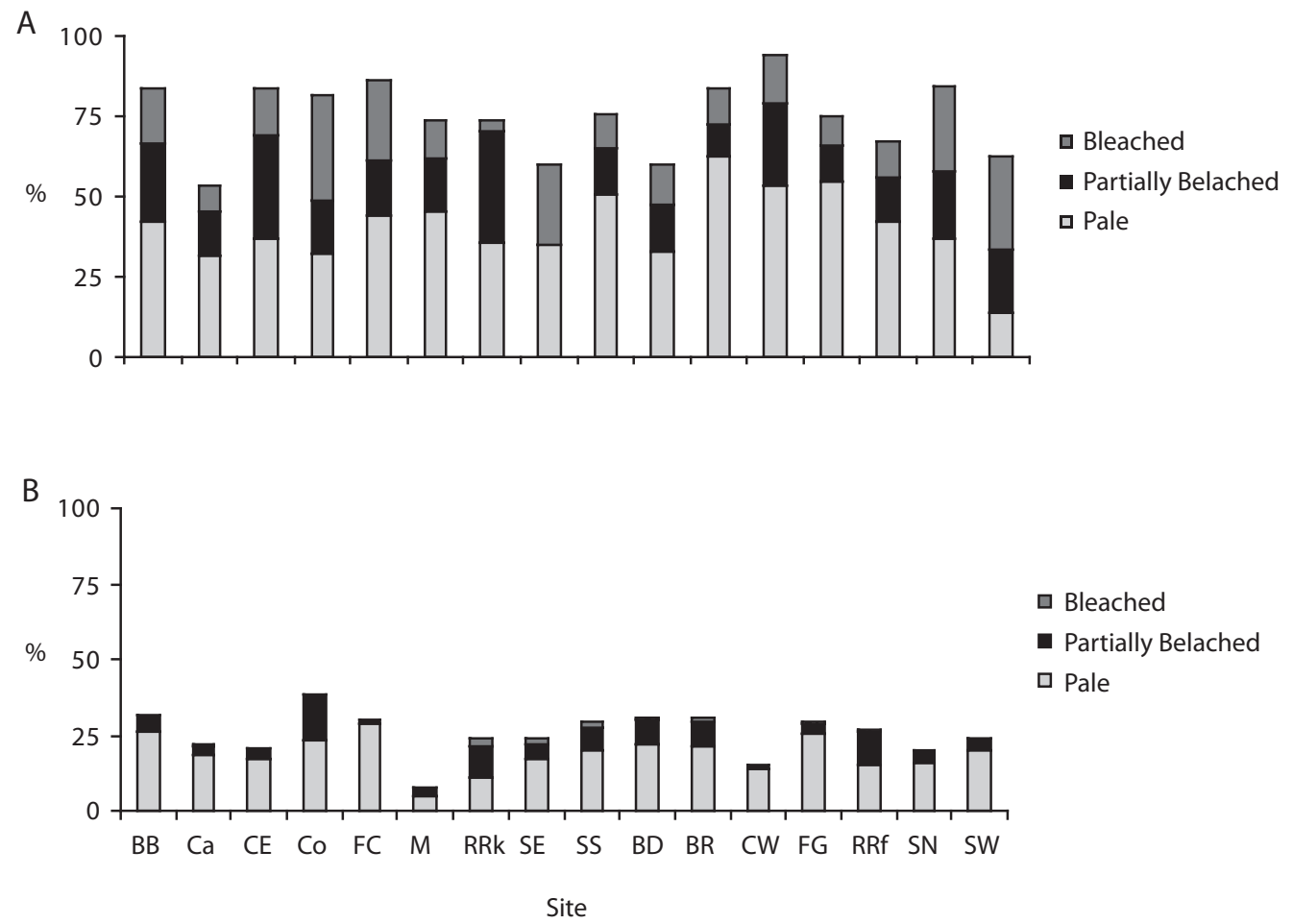

Fig. 1. Prevalence of partially bleached, pale and bleached colonies per site in (a) 2005 and (b) 2006.

completely bleached colonies exceeded $50 \%$ in only four of these species, including the framework building $D$. strigosa. One percent of the colonies were fully bleached. All shallow sites again had a significantly higher prevalence of bleaching symptoms and fully bleached colonies than deep sites (TPP, $\mathrm{z}=2.23, \mathrm{p}<0.05$ ). Tissue loss due to recent mortality was evident at all sites, ranging from 1 - $29 \%$ coral surface area (Fig. 2) with an overall increase of 10\%, and was significantly higher at deep sites than at shallow sites (TPP, $\mathrm{z}=2.39, \mathrm{p}<0.05$ ). Among the framework building species, $M$. annularis, $M$. faveolata and $S$. siderea were most affected by recent tissue loss (Fig. 3). Apart from the absent $A$. agaricites, $P$. astreoides was the most affected of the smaller corals. A significant decrease in live coral cover (TPP, $\mathrm{z} \geq 2.25$, $\mathrm{p}<0.05$ ) was observed at 3 sites (Fig. 4). Mean live coral cover decreased by $28.4 \%$ between 2005 and 2006 when line-intercept data are compared. Similar results $(29 \%$ coral cover decrease) were obtained using cover estimates derived from the product of "colony length and width in planar view" (see Kramer et al. 2005). By the end of 2006, mean live coral cover at shallow sites was $17.5 \%( \pm 5 \%)$ and at deep sites $19 \%( \pm 2.3 \%)$.

In 2005 a total of 556 coral recruits were found, 532 belonging to 23 species identified in situ, while 24 recruits could not be identified (Figs. 5 and 6). Scleractinian recruits in (medium-large species) were dominated by $A$. agaricites at deep sites (36\%) and shallow sites (24\%) where $P$. astreoides also contributed $24 \%$ of the recruits. Between 2005 and 2006, the abundance of coral recruits decreased at all sites except Batali. In 2006, 203 recruits were found belonging to 26 species identified in situ. Among the common recruits, $A$. agaricites, $S$. siderea, and P. astreoides had 77\%, 53\%, and 27.8\% fewer recruits in 2006 than 2005 (Fig. 


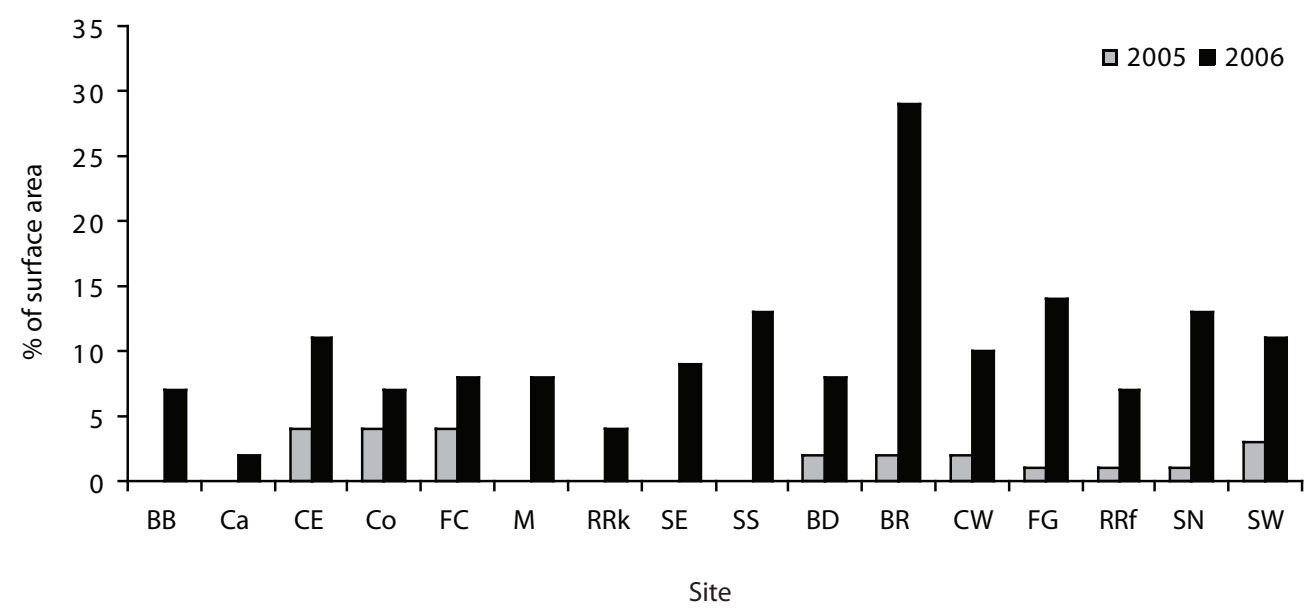

Fig. 2. Recent partial mortality estimates (\% surface area) of colonies per site in 2005 and 2006.

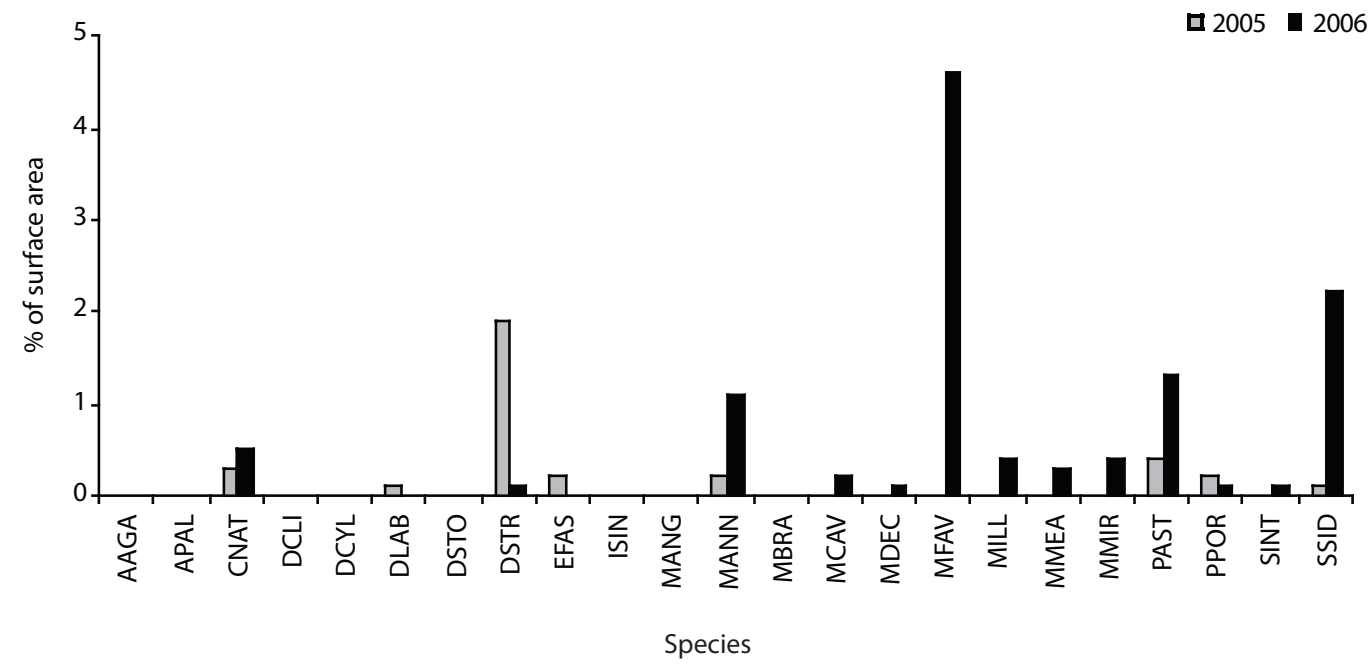

Fig. 3. Recent partial mortality estimates (\% surface area) by species in 2005 and 2006.

6). With the exception of S. siderea, framework building species had few recruits in both years. Overall, recruit abundance decreased significantly (t-test, t-stat $=4.627, \mathrm{df}=30$, $\mathrm{p}<0.05$ ) by $65 \%$ from 14.23 recruits per $\mathrm{m}^{2}$ to 4.92 recruits per $\mathrm{m}^{2}$. No significant difference in coral recruit density was observed between shallow and deep sites in both years.

\section{DISCUSSION}

The bleaching episode of 2005 was the first to be quantitatively assessed in Dominica and affected $76 \%$ of all surveyed colonies. Based on a replicate survey one year later, live coral cover had decreased by $28 \%$, recent mortality, which was significantly higher at 


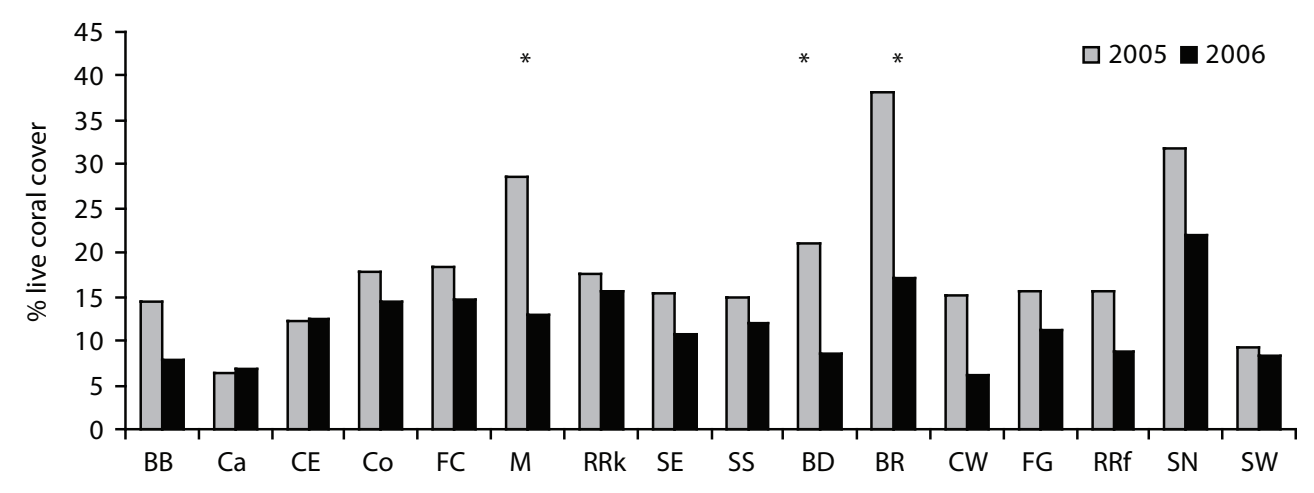

Site

Fig. 4. Live coral cover under transect line per site 2005 and 2006; * = significant decreases $(p<0.05)$ in 2006.

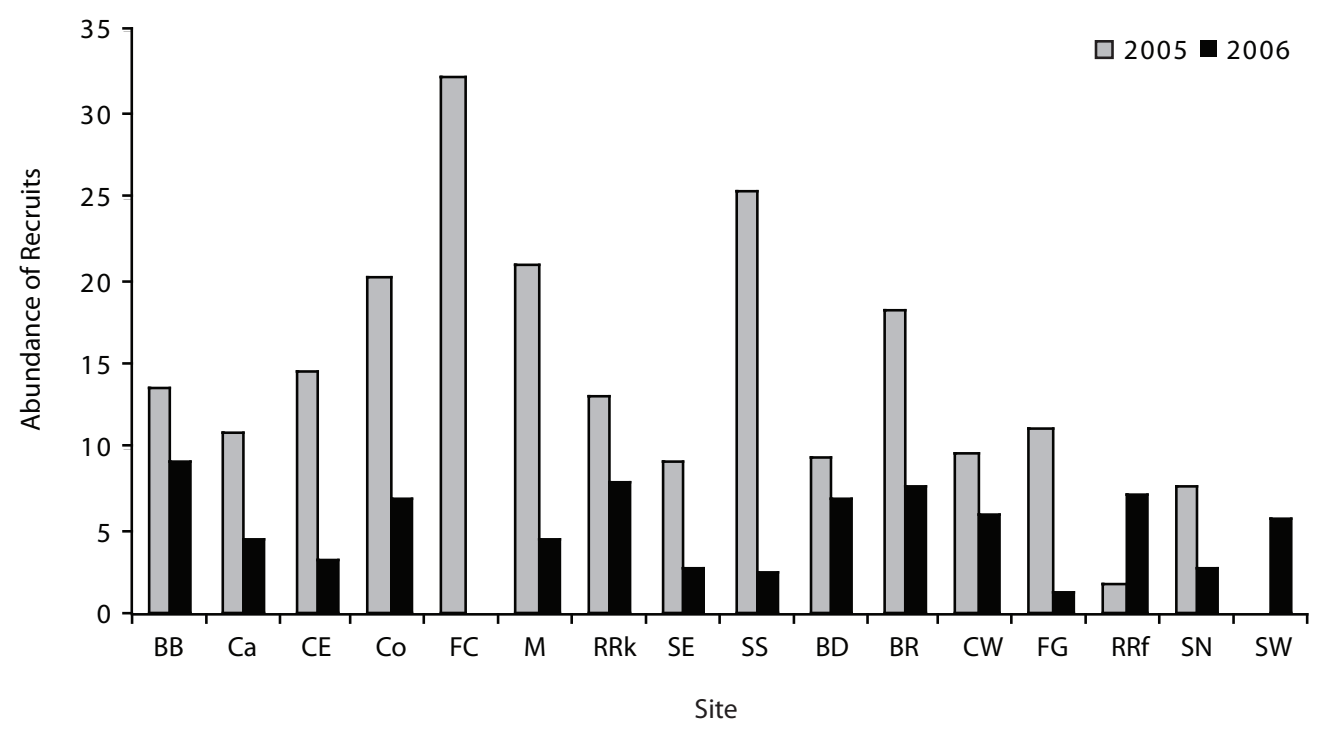

Fig. 5. Abundance (colonies $\mathrm{m}^{-2}$ ) of coral recruits per site in 2005 and 2006.

deeper sites than shallow sites, had increased by $10 \%$, and the abundance of recruits had decreased by 65\%. Although 2006 was not considered a "bleaching year" based on sea surface temperatures, $26 \%$ of coral colonies exhibited symptoms of bleaching. In the absence of field observation from the summer 2006, it remains unclear to what extent this represented a delayed recovery and or a resurgence of mild bleaching in already weakened corals.
Given the slow (months) recovery from these disturbances, the weakened state of coral communities persists well beyond the periods of acute thermal stresses as observed in 2003 and 2004 when individual colonies remained pale or bleached for 6-7 months (unpublished data). Short-term consequences of such events include corals being more susceptibility to coral pathogens or mortality induced by additional stressors (Hoegh-Guldberg 1999). Bleached 


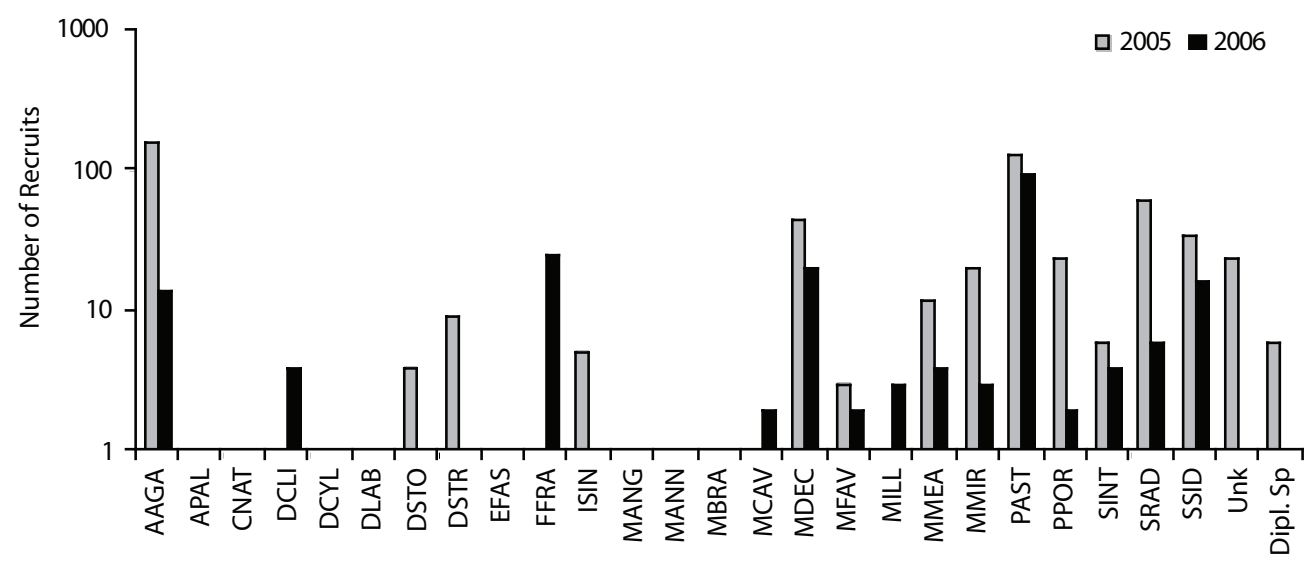

Species

Fig. 6. Number of coral recruits per species 2005 and 2006.

corals are also known to be unable to complete gametogenesis during the reproductive season following the bleaching (Szmant \& Gassman 1990). The substantial decrease in recruits from 2005 to 2006 may have resulted form the combined effects of recruit mortality during and after the 2005 bleaching episode, and reduced reproductive output due to a reduction in parent colonies as well as weakened surviving colonies with disrupted gametogenesis (Jokiel and Coles 1990, Hoegh-Guldberg 1999, Baird and Marshall 2002). Increased mortality of established corals and reduced recruitment both underscore the long-lasting consequences of a single, widespread bleaching episode in Dominica. Moreover, if coral populations on islands such as Dominica, represent reproductively rather isolated entities, similar to the regionally isolated A. palmata (see Baums et al. 2005) and Acropora cervicornis (see Vollmer and Palumbi 2007), the consequences of reductions in fecundity (Szmant \& Gassman 1990), in particular among poor recruiters (see Szmant 1986), can lead to dramatic alterations in the reefs' species composition and architecture. The 2005 event followed bleaching in the years 2003 and 2004. While each of these events differed in terms of SST range and duration, onset of bleaching symptoms, sequence of species and abundance of colonies affected (unpublished data), as well as additional stressors (e.g. sedimentation, hypo-salinity), all have contributed to the chronic disturbances shaping Dominica's coral communities.

Corals in deep (6-18 m) sites were significantly less affected by bleaching symptoms than those of shallow sites. One year later recent coral mortality, however, was significantly higher at the deep sites. So while coral bleaching in shallow habitats was more widespread, deeper corals did not recover as well as their shallow water counterparts, undermining the potential of Dominica's deeper reefs as refugia at least within the here examined depth range (see also Warner et al. 1999, Riegl \& Piller 2003). Similarly, planula larvae from deep sites may generally be more sensitive to UVB radiation and mortality than larvae from shallow sites as demonstrated by Gleason and Wellington (1995) for A. agaricites. Deep reefs may therefore contribute to reduced recruitment rates should bleaching events occur during the spawning or planulation phase of particular corals. Conversely, bleached shallow-water corals, may benefit from diurnal temperature fluctuations, as well as a quicker onset of the cooling-off periods during days 
with strong insulation and low wind speed (see Katsaros 2004).

It could not be determined how much of the recent coral mortality observed in 2006 was directly attributed to bleaching or to diseases as affected colonies were not marked and observed over time. Borger and Steiner (2005) reported $8 \mathrm{~m}^{2}$ tissue loss ( $<2 \%$ of examined coral cover) due to disease-induced mortality ( $80 \%$ white plague) on marked colonies belonging to 16 species between 2000 and 2002 when no mass coral bleaching occurred in Dominica. In 2004, the least severe of 3 consecutive bleaching years (2003, 2004 and 2005), disease prevalence was low, yet yellow band disease was common in $M$. faveolata (J. Kerr unpublished data). In 2005 and 2006, coral disease prevalence remained low. However, during the bleaching episode of 2005, identifying the manifestations and diseases that did not contrast (in terms of color) on pale and bleached corals of "white reefs" was difficult, and the low prevalence may be an artifact.

The increasing frequency and severity of mass coral bleaching episodes represent additional disturbances exacerbating the effect of previous and current anthropogenic disturbances on the marginal reef systems of Dominica. For the past 3 centuries Dominica's reefs and coral communities have been exposed to a series of heavy uses and additions (sensu GESAMP 1990). These have come in the form of coral mining, fishing, coastal zone degradation as well as inputs from agricultural and urban centers. Coral mining for the production of lime was an important means for infrastructural development such as the construction of forts, agricultural estates and towns, and a practice that continued into the 1950s prior to the ready availability of cement. Although fisheries are artisanal in terms of gear, all nearshore marine habitats are fished with a variety of methods including fish pots (on reefs), seine nets (in sandy bays and sea grass beds), a variety of line fishing techniques, and more recently also spear-fishing. Increased sediment runoff caused by deforestation, gravel and sand mining and coastal sprawl, as well as the input of fertilizers, pesticides and sewage are among the primary sources of anthropogenic disturbance. The number local and regional disturbances keeps growing, highlighting the importance of any action counteracting this trend if Dominica's remaining coral resources are to have a chance of being conserved.

\section{ACKNOWLEDGMENTS}

We thank, M. Jordan, J. McNeal, N. Wallover, R. Zuercher, K. Byrd for their field assistance in 2005, and C. Davis, S. Laffan, J. Sabattis, J. Weems in 2006. Logistic and financial support for this project was provided by the Institute for Tropical Marine Ecology Inc. (ITME RPfa05/06)

\section{RESUMEN}

En el 2005, el protocolo de AGRRA (Atlantic and Gulf Rapid Reef Assessment) fue implementado por primera vez en Dominica, entre el 20 de octubre y el 18 de noviembre. Durante ese mismo período, las temperaturas superficiales del mar subieron de manera anómala, causando el blanqueamiento más severo observado en el Caribe. Diez y nueve de las 20 especies de coral que se estudiaron, estaban afectadas. La presencia de corales pálidos, parcialmente blanqueados o completamente blanqueados excedió el $50 \%$ en 13 de estas especies, y el 76\% de las colonias ( $n$ = 1475) tenía algún tipo de blanqueamiento. Para evaluar el impacto de este evento sobre los corales de Dominica, los 16 sitios estudiados en el 2005 fueron re-examinados en el 2006 (17 de octubre - 25 de noviembre) con los mismos métodos. Veinte de las 23 especies estudiadas estaban afectadas, la presencia de corales pálidos, parcialmente blanqueados o completamente blanqueados excedió el $50 \%$ en solo cuatro especies, y el $26 \%$ de las colonias ( $n$ = 1407) tenía síntomas de blanqueamiento. Sin embargo, la cobertura de corales vivos disminuyó $28 \%$, la mortalidad reciente aumentó $10 \%$, y la abundancia de reclutas de corales disminuyó 65\%. Agaricia agaricites, un coral común en los arrecifes de Dominica antes del 2005, fue una de las especies más afectadas, y para el estudio del 2006, ya no se le encontró. Los sitios profundos (6-18 m) fueron más afectados por la mortalidad reciente de corales que los sitos someros, lo cual desmiente la idea de que los sitios profundos pueden funcionar como refugios. En Dominica, además del blanqueamiento del 2005, hubo otros en 2003 y 2004. El impacto crónico de este tipo de eventos, combinado con disturbios comunes como escorrentía de sedimentos (canteras, desarrollo costero), contaminación (desperdicios sólidos, aguas servidas y plaguicidas) y pesquería (pesca 
con arbaleta, trampas y redes de encierro), los sistemas de arrecifes marginales de Dominica están siendo expuestos a estrés sin precedentes. Estos resultados resaltan la urgencia de actuar para reducir los impactos humanos, a fin de conservar los recursos arrecifales de Dominica.

Palabras clave: blanqueamiento de corales, Dominica, mortalidad, reclutamiento.

\section{REFERENCES}

Baums, I.A., M.W. Miller \& M.E. Hellberg. 2005. Regionally isolated populations of an imperiled Caribbean coral, Acropora palmata. Molec. Ecol. 14: 1377-1390.

Baird, A.H. \& P.A. Marshall. 2002. Mortality, growth and reproduction in scleractinian corals following bleaching on the great barrier reef. Mar. Ecol. Prog. Ser. 273: 133-141.

Borger, J. \& S.C.C. Steiner. 2005. The spatial and temporal dynamics of coral diseases in Dominica. Bull. Mar. Sci. 77: 137-154.

GESAMP. 1990. The state of the marine environment. GESAMP Reports and Studies 39:1-111.

Gleason, D.F. \& G.M. Wellington. 1995. Variation in UVB sensitivity of planula larvae of the coral Agaricia agaricites along depth gradient. Mar. Biol. 123:693-703.

Glynn, P.W. 1993. Coral reef bleaching: ecological perspectives. Coral Reefs 12: 1-17.

Hoegh-Guldberg, O. 1999. Climate change, coral bleaching and the future of the world's coral reefs. Mar. Freshw. Res. 50: 839-866.

Humann, P. 1994. Reef Coral Identification. New World, Jacksonville, Florida, USA. 239 pp.

Jokiel, P.L. \& S.L. Coles. 1990. Response of Hawaiian and other Indo-Pacific reef corals to elevated temperatures. Coral Reefs 8: 155-162.

Katsaros, K.B. 2004. Weakening of horizontal sea surface temperature gradients at low wind speeds with strong insolation. Gayana 68 (Suppl. 2): 305-310.
Lesser, M.P., W.R. Stochaj, D.W. Tapley \& J.M. Shick. 1990. Bleaching in coral reef anthozoans: effects of irradiance, ultraviolet radiation and temperature on the activities of proactive enzymes against active oxygen. Coral Reefs 8: 225-232.

Ramsey, F.L. \& D.W. Schafer. 1997. The Statistical Sleuth: A Course in Methods of Data Analysis. 672 p. Duxbury, Belmont, California, USA.

Riegl, B. \& W.E. Piller. 2003. Possible refugia for reefs in times of environmental stress. Int. J. Earth Sci. 92: 520-531.

Shein, K.A. 2006. State of the climate in 2005. Bull. Am. Meteorol. Soc. 87: 1-102.

Steiner, S.C.C. 2003. Stony corals and reefs of Dominica. Atoll Res. Bull. 498: 1-15.

Szmant, A. 1986. Reproductive ecology of the Caribbean reef corals. Coral Reefs 5: 43-54.

Szmant, A. \& N.J. Gassman. 1990. The effects of prolonged bleaching on the tissue biomass and reproduction of the reef coral Montastrea anularis. Coral Reefs 8: 217-224.

Vollmer, S.V. \& S.R. Palumbi. 2007. Restricted gene flow in the Caribbean staghorn coral Acropora cervicornis: Implications for the recovery of endangered reefs. J. Heredity 2007: 40-50.

Warner, M.E., W.K. Fitt \& G.W. Schmidt. 1999. Damage to photosystem II in symbiotic dinoflagellates: A determinant or coral bleaching. Proc. Natl. Acad. Sci. 96: 8007-8012.

Williams, E.H., Jr. \& L. Bunkley-Williams. 1990. The world wide coral bleaching cycle and related sources of coral mortality. Atoll Res. Bull. 335: 1-71.

\section{INTERNET REFERENCES}

Kramer, P., J. Lang., K. Marks, R. Garza \& R. Ginsburg. 2005. AGRRA Methodology v. 4.0 Atlantic and Gulf Rapid Reef Assessment v. 4.0:1-14. downloaded from www.agrra.org. 